\title{
Magdalena Biniaś-Szkopek: Matżonkowie przed sądem biskupiego oficjała poznańskiego $w$ pierwszej ćwierci XV wieku. Poznań, Instytut Historii UAM, 2018, ss. 293.
}

Praca Magdaleny Biniaś-Szkopek podejmuje problematykę bardzo ważną dla badań zarówno nad życiem codziennym (sprawy małżeńskie, życie rodzinne, pozycja kobiety), jak i nad praktyką funkcjonowania sądownictwa biskupiego, a także nad wpływem prawa kanonicznego na społeczeństwo w późnośredniowiecznej Polsce. Te zagadnienia były poruszane przez historyków polskich w tekstach sprzed wielu dziesiątków lat, a i w ostatnim czasie ponownie cieszą się zainteresowaniem (zob. zestawienie literatury w omawianej książce), dalekie są jednak od wyczerpania. Podstawą źródłową tomu jest analiza wpisów do ksiąg konsystorskich, w tym wypadku poznańskich. Autorka zebrała 550 procesów małżeńskich (causae matrimoniales) z lat 1404-1426 (luka dla lat 1412 - 1416), noty o których zachowane są w dziewięciu najstarszych księgach tegoż urzędu (AC1-AC9) (s. 16 i 17).

Omawiana monografia składa się z trzech głównych części, z których każda kończy się podsumowaniem. Całość jest poprzedzona krótkim wprowadzeniem oraz dopełniona zakończeniem; ponadto zawiera bibliografię, indeksy oraz streszczenie w języku angielskim.

W pierwszej części: Matżństwo $w$ dokumentach kościelnych a praktyka sądów konsystorskich w średniowieczu (s. 27-93), otrzymujemy wprowadzenie w zasadniczą materię. Biniaś-Szkopek omawia kształtowanie się koncepcji małżeństwa w prawie kanonicznym oraz recepcję prawa powszechnego w Polsce i w diecezji poznańskiej (s. 29-56: rozdz. Małżeństwo w średniowieczu $w$ świetle wybranych dokumentów i pism Kościoła). Następnie w podrozdziale zatytułowanym Sady konsystorskie w Polsce — powstanie i praktyka działania (s. 57-93) prezentuje: zarys dziejów urzędu oficjała w Polsce, wytworzone przez polskie konsystorze akta, ze szczególnym zwróceniem uwagi na 
acta causarum konsystorza poznańskiego, dalej kompetencje i funkcjonowanie konsystorza poznańskiego, a wreszcie krótki ekskurs o osobach, które przed tym konsystorzem stawały ze swoimi sprawami małżeńskimi (2.5. Matżonkowie przed obliczem oficjała poznańskiego, czyli kto sądzit się w sądzie konsystorskim, s. 83-91).

Druga i trzecia część są poświęcone analizie materiału źródłowego. Autorka podzieliła materię na dwie duże grupy. Jako pierwsze omawia sprawy, które dotyczyły obietnicy małżeństwa oraz całej problematyki łączącej się z formalnością zawarcia związku małżeńskiego uznanego przez Kościół za legalny (część II: Wokół obietnicy matżeńskiej, s. 95-159). W tej części poruszane są następujące kwestie: małżeństwa tajemne, konkubinat, związki zawarte tylko poprzez świeckie ceremonie (s. 99-110) oraz problemy związane z obietnicą małżeńską, czyli niedotrzymanie przysięgi małżeńskiej, nakaz milczenia dla niedoszłych małżonków (w wypadku zgłaszania przez nich sprzeciwu wobec chęci zawarcia przez dawną narzeczoną/dawnego narzeczonego małżeństwa; s. 111-133), sprawy dotyczące pohańbienia lub zgwałcenia kobiety; te czyny w większości znanych autorce przypadków były powiązane z jakąś formą obietnicy małżeństwa (s. 134-142). Na koniec tej części przedstawiono sprawy, w których znane są nie tylko petycje składane przez (nie)małżonków, ale także postanowienia sędziów - wiemy zatem, jak procedowali w sprawach dotyczących obietnicy małżeństwa (s. 143-154).

Drugą grupą są sprawy związane z przeszkodami małżeńskimi, zarówno tymi, które były podstawą do uznania związku za niebyły, jak i takimi, które nie unieważniały małżeństwa (część III: $W$ kręgu matżeńskich przeszkód, s. 161-241). Autorka, idąc za materią źródeł, wyróżnia następujące zagadnienia: sprawy o bigamię (s. 166-180), impotencję (s. 181-198), przymus przy zawieraniu małżeństwa (s. 199-213), pokrewieństwo i powinowactwo (s. 214-222), wreszcie przemoc oraz cudzołóstwo (s. 223-241).

Każdy z podrozdziałów rozpoczyna się streszczeniem przykładowej sprawy, charakterystycznej dla kategorii omawianej w danej części; towarzyszy temu zdjęcie stosownego fragmentu z ksiąg konsystorskich. Prezentację materiału źródłowego wzbogacają wykresy oraz — w niektórych przypadkach — także tabele.

Autorka wyróżniła kilka celów, jakie zamierzała zrealizować w swojej rozprawie. Pierwszym było „przedstawienie materiału źródłowego dotychczas nieznanego historiografii”, następnie „wybór i przeprowadzenie statystyk dla znalezionych w księgach not”, a to miało służyć „odtworzeniu obrazu problemów nękających [...] małżeństwa" w pierwszej ćwierci XV wieku w diecezji poznańskiej (s. 13). Ponadto „ważnym celem zrealizowanym w pracy było omówienie funkcjonowania konsystorza poznańskiego, wymienienie rodzajów rozpatrywanych w nim procesów, zakresu jego władzy oraz stosowanego systemu kancelaryjnego (jednak tylko w wymiarze niezbędnym dla 
realizacji nadrzędnego celu, jakim było opowiedzenie o problemach małżeńskich)" (s. 13).

Wykonanie zamierzonych zadań nasuwa różne uwagi. Już sam tytuł wzbudza wątpliwości. Niefortunnym określeniem jest „sąd biskupiego oficjała”; oficjał to sędzia biskupi. Sformułowanie ,przed sądem oficjała” byłoby wystarczające. Pojawia się dodatkowa wątpliwość natury źródłowej. Podstawą rozważań Biniaś-Szkopek są acta causarum wytworzone nie tylko przez oficjała, ale także wikariusza generalnego. Autorka jest doskonale tego świadoma, prezentując źródła i zauważając, że poza kilkoma wskazanymi latami „,w pozostałych przypadkach zapisy działalności wikariuszy łączą się w jednej księdze z zapisami oficjałów, co świadczy o koncepcji połączenia tych urzędów w jednym ręku już w pierwszej połowie XV wieku" (s. 71). Ponadto zwraca uwagę na podobne kompetencje obydwu urzędników — podkreślmy, że w gestii jednego i drugiego leżało rozstrzyganie spraw małżeńskich - co sprzyjało łączeniu tych dwóch urzędów w jednym ręku.

Bohaterami omawianej tu książki nie są tylko małżonkowie, a może nawet w większości nie są to małżonkowie, ale osoby pozostające w różnych związkach lub pomiędzy którymi doszło do jakichś form układów/obietnic/ kontaktów, mających — przynajmniej w mniemaniu jednej ze stron — zaowocować małżeństwem. Co więcej, możemy wręcz założyć, że ze względu na charakter sądu i jego kompetencje większość trafiających do niego spraw małżeńskich nie była wnoszona przez małżonków. Autorka jest tego świadoma. Jak sama zaznacza, w przypadku 330 spraw (na 550), które omawia w części II (zatytułowanej nawet Wokół obietnicy małżeńskiej), chodziło o problem ważności — w świetle prawa kanonicznego — relacji pomiędzy kobietą i mężczyzną oraz ewentualnego uznania tej relacji za małżeństwo lub też przymuszenia jednej ze stron do wypełnienia podjętego zobowiązania (s. 111). Zatem w wypadku tych osób, a dotyczy to ponad połowy spraw, trudno mówić o małżonkach. Nawet samo sformułowanie tytułu drugiego rozdziału w tej części zawiera błąd logiczny: Małżonkowie walczący o zatwierdzenie ważności obietnicy mał̇̇ńskiej przed poznańskim oficjatem (s. 111). Skoro (nie)para jest na etapie walki o zatwierdzenie ważności obietnicy zawarcia związku małżeńskiego, to na pewno osoby te nie są jeszcze małżonkami.

W części III większość omawianych spraw dotyczy przeszkód zrywających związki (wcześniej zawarte małżeństwo, zbyt bliski stopień pokrewieństwa lub powinowactwa, przymus przy wyrażaniu zgody na ślub itp.), a więc i w tym przypadku przed sądem stawały osoby, które w wielu wypadkach formalnie nie były małżonkami (choć mogły być małżonkami innych osób, jak np. bigamiści/stki, największa grupa spośród omawianych w tym rozdziale - 136; s. 164). Przedmiotem rozprawy było rozpoznanie, czy daną parę łączą legalne - w rozumieniu prawa kanonicznego — więzy małżeńskie. 
Stan stron prowadzących w sądzie kościelnym spory w kwestiach małżeńskich był zatem bardzo różny: małżonkowie, narzeczeni, byli narzeczeni, konkubenci, małżonkowie w rozumieniu społecznym (po zawarciu związku poprzez ceremonie świeckie), ludzie wolni. Uprawnione jest więc mówienie o sprawach małżeńskich przed obliczem oficjała. Możemy się domyślać, że zwrócenie uwagi w tytule na osoby miało wskazywać, że autorka chce zająć się przede wszystkim ludźmi i z ich perspektywy spojrzeć na problemy małżeńskie. Jednak Biniaś-Szkopek buduje swoją narrację według poszczególnych kategorii spraw. To one wyznaczają układ rozdziałów. Oczywiście to ludzie opowiadali przed sądem o swoich problemach i to ludzie są bohaterami obficie przytaczanych przez autorkę skomplikowanych, dramatycznych, a nawet pikantnych historii. Jednak to sprawy są głównymi „bohaterami” książki. Z powodu niejasności w kwestiach zawarcia związku małżeńskiego, z powodu niejasności w kwestiach istnienia prawego związku małżeńskiego, z powodu unikania wypełnienia zobowiązań małżeńskich ludzie stawali przed konsystorzem. Tylko w jednym podrozdziale autorka wyraźnie skupia się na samych osobach, unikając nawet identyfikowania ich według kategorii przestępstw, jakich się dopuścili, co robi na kartach prawie całej książki (bigamiści/stki, impotenci/oziębłe, kazirodcy, uwodziciele, oprawcy, trucicielki, cudzołożnicy/e itp.). W podrozdziale 2.5 części I (Matżonkowie przed obliczem oficjała poznańskiego, czyli kto sadzit się w sadzie konsystorskim) otrzymujemy próbę analizy społecznej grupy osób występujących przed sądem konsystorskim. Próba ta budzi duży niedosyt. Co prawda, autorka zaznacza, że zamierza poświęcić osobną pracę osobom przybywającym do sądu konsystorskiego w Poznaniu (s. 91, przyp. 281), jednak sygnalizując (słusznie!) ten temat w omawianej tu monografii, traktuje go wyjątkowo marginalnie. Przedstawia jedynie zestawienia tabelaryczne: zawody kobiet i mężczyzn przybywających do konsystorza (oczywiście dla tych osób, w wypadku których takie informacje zostały zapisane w aktach konsystorskich) oraz imiona kobiet i mężczyzn. W skąpym komentarzu brak nawet hipotez lub prób interpretacji tego materiału. Ponadto nawet pobieżny ogląd zestawień ujawnia różne błędy. Jako przykład wskażmy pomyłki w wykazach imion. Biniaś-Szkopek przy niektórych imionach podaje obok formy podstawowej także inne formy danego imienia odnotowane w źródłach konsystorskich, ale liczbę wystąpień podaje zbiorczo, np. Elżbieta (Elisabeth, Elisabet, Helisabeth, Sbyetha) - liczba wystąpień aż 46 (s. 87). Niezrozumiałe jest zatem, dlaczego w wypadku imienia Agnieszka autorka zdecydowała się na wyróżnienie osobnych trzech grup kobiet je noszących: Agnieszka (Agnes, Agnesca, Agneta) - 26 kobiet, Jachna - 2, Jagna - 11 (s. 87). Oczywiście interesujące jest, jaką popularnością cieszyły się poszczególne wersje imienia, ale nic nie stało na przeszkodzie, by to uwzględnić, jednocześnie podając ogólną liczbę wystąpień imienia Agnieszka $(26+2+11$ = 39). $\mathrm{W}$ wypadku np. analizy popularności świętych trzeba brać pod uwagę 
łącznie wszystkie wersje danego imienia. Należy też zauważyć, że Paszko (1) to forma imienia Paweł (18) (s. 90), a zatem w poznańskich księgach konsystorskich z pierwszej ćwierci XV wieku odnotowano 19 Pawłów. Natomiast Venceslaus to Wacław, nie Wieńczysław (s. 91).

Za błąd konstrukcyjny należy uznać umieszczenie omówienia grupy osób stających przed sądem jako podrozdziału w rozdziale poświęconyn sądom konsystorskim w Polsce. Nawet jeżeli autorka od początku planowała przedstawić jedynie szkic problemu, jest to kwestia odrębna, która winna i w konstrukcji pracy zyskać miejsce osobne.

Koncepcja omawianej książki nie jest jasna. Badaczka podąża za materią źródeł, co nie jest błędem, wszak to źródła wytyczają nam zakres możliwości badawczych. Tego, czego w źródłach nie ma, nie możemy z nich wyczytać. Trzymanie się zatem przez autorkę źródeł jest ogromną zaletą. Możemy też uznać, że jeden z postawionych przez Biniaś-Szkopek celów — ,przedstawienie materiału źródłowego dotychczas nieznanego historiografii" (s. 13) został zrealizowany. Praca wprowadza w obieg naukowy duży i pasjonujący materiał archiwalny, jakim są procesy w sprawach małżeńskich w pierwszej ćwierci XV wieku. Sądzę, że ten materiał będzie wielokrotnie wykorzystywany przez innych historyków. Autorka uległa jednak niebezpieczeństwu opowiadania smakowitych, pikantnych, dramatycznych lub plotkarskich historii o przodkach. To zdarza się $\mathrm{w}$ pracy $\mathrm{z}$ materiałem archiwalnym, w którym mamy wielu bohaterów i ciągle zmieniającą się akcję. Tytułem usprawiedliwienia dodajmy, że uniknięcie tej pokusy jest bardzo trudne. Zresztą nie chcę sugerować, że NIE należy relacjonować tego, co w niepublikowanych źródłach autor, często z niemałym trudem, wyczytał. To ważne, potrzebne, a i miłe dla czytelnika. Od opracowań naukowych oczekujemy jednak także analizy prezentowanego materiału.

Narracja w omawianej pracy jest zbudowana na analizie poszczególnych grup spraw małżeńskich. Można odnieść wrażenie, że autorka wyróżniła dwie główne fazy życia ludzi, którzy przybywali do konsystorza. Pierwszą — przed małżeństwem (obietnica, często w przedstawianych przypadkach złudna Wokót obietnicy matżeńskiej), oraz drugą — po lub wokoło momentu zawarcia związku ( $W$ kręgu matżeńskich przeszkód). Następnie materiał przypisany do każdej z grup podzieliła na kategorie szczegółowe. Zarówno kryteria podziału na dwie zasadnicze grupy, jak i klasyfikacje w ich obrębie nie są w pełni jasne. Nie pochodzą ze źródeł, gdzie nie wyodrębniano spraw w osobne kategorie, a są propozycją autorki. Już na poziomie ogólnego podziału na dwie duże grupy mamy wątpliwości. Dlaczego bowiem małżeństwa tajemne, konkubinaty, związki zawarte tylko poprzez ceremonię świecką, czyli też konkubinaty w rozumieniu prawa kanonicznego (Matrimonia clandestina, konkubinaty, świeckie obrzędy, czyli sprawcy największych problemów, s. 99-110), zostały zaliczone do kategorii problemów związanych z niedotrzymaniem obietnicy 
małżeństwa? W tych przypadkach problem nie leżał w niedotrzymaniu zobowiązania, ale w statusie związku, który w ocenie kanonicznej małżeństwem nie był, a w ocenie społecznej mógł być akceptowany jako legalny.

Na marginesie dodajmy, że w prezentowanych przez Biniaś-Szkopek sprawach w tym rozdziale często pojawiają się opisy różnych elementów ceremonii świeckich, co stanowi kapitalny materiał, który wzbogaca naszą wiedzę na temat praktyki ceremonii świeckiej w pierwszej ćwierci XV wieku w diecezji poznańskiej. Ta kwestia wychodzi już poza ramy problematyki omawianej książki. Należy jednak zachęcać autorkę do podjęcia jej w jednej z kolejnych publikacji.

Cały zbiór spraw omawianych w części drugiej, a jest to dobrze ponad połowa (330 na 550) wszystkich przypadków, rodzi — jak można odnieść wrażenie - kłopoty klasyfikacyjne i interpretacyjne. Otrzymujemy właściwie zestaw różnych historii, z których jednak nie jest budowany jakiś szerszy obraz. Trzeba przyznać, że badaczka czyni takie próby. Chyba najciekawszym fragmentem jest ten poświęcony zmaganiom oficjałów z problemami wnoszonymi przed ich trybunał. Biniaś-Szkopek uchwyciła w tym materiale praktykę dziatania prawa kanonicznego.

W części trzeciej pracy (czyli „po zawarciu małżeństwa”) klasyfikacja wydaje się prostsza i bardziej przejrzysta: bigamia, a nawet wielożeństwo, przeszkoda pokrewieństwa i/lub powinowactwa, impotencja, przymus przy zawieraniu małżeństwa itp. Autorka o wiele sprawniej i pewniej porusza się wśród omawianych przypadków. Czytelnik również otrzymuje klarowny wgląd $\mathrm{w}$ materię sporów miedzy (nie)małżonkami z pierwszej ćwierci XV wieku z diecezji poznańskiej. Spraw toczących się wokół przeszkód małżeńskich jest mniej niż w części wcześniejszej - 252. Dodać trzeba, że liczba spraw z pierwszej i drugiej części przewyższa liczbę spraw małżeńskich, jakie są podstawą badań Biniaś-Szkopek. Przyczyna jest prosta. W części spraw materia sporu między stronami może być przypisana do więcej niż jednej kategorii. Autorka o tym wspomina, szkoda jednak, że nie analizuje, albo chociaż nie opisuje dokładniej, tego zjawiska. Może dałoby się odnaleźć jakieś zależności? Wiele też by to wniosło do poznania codzienności relacji między kobietami i mężczyznami w początkach XV wieku.

Do mankamentów pracy należy zaliczyć brak zarysowania obrazu ogólnego. Jeden z celów autorki to „wybór i przeprowadzenie statystyk dla znalezionych w księgach not" (s. 13). I odnajdujemy statystyki dla obydwu głównych grup spraw, czyli omawianych w drugiej (s. 112) i trzeciej części (s. 164), ponadto są też zamieszczone statystyki dla niektórych kategorii szczegółowych, jak sprawy o surpo i defloratio (s. 136), bigamia (s. 167), impotencja (s. 186). Brak jednak choćby jednego zestawienia wszystkich spraw lub wszystkich wyróżnionych przez autorkę problemów wraz z analizą ogólną lub próbą postawienia hipotez. Nie otrzymujemy refleksji na temat różnych zagadnień 
społecznych, prawnych, dotyczących historii mentalności, jak rozumienie legalności małżeństwa w wybranym czasie i na wybranym obszarze, wpływ prawa kanonicznego na przemiany obyczajowe, koegzystencja/włączanie norm miejscowych w normy powszechne, pozycja kobiety, status relacji małżeńskiej itp. A także działania samego konsystorza.

W tej ostatniej kwestii już sam ogląd wykresu 2.1. „Liczba spraw małżeńskich, w zestawieniu z liczbą spraw o ważność związku z lat 1404-1426" (s. 112) pokazuje, że $\mathrm{w}$ działaniu poznańskiego konsystorza na przestrzeni lat 1404-1426 (z uwzględnieniem luki lat 1412-1416) zachodziły wyraźne zmiany. Widzimy duże różnice w liczbie procedowanych spraw małżeńskich. W latach 1404—1419 było to zaledwie kilka—kilkanaście spraw rocznie, po czym obserwujemy gwałtowny przyrost: ok. 50 dla lat 1420 (48) i 1421 (56), aż do ok. 100 dla lat 1425 (98) i 1426 (109). Czy ta tendencja utrzymała się w kolejnych latach? Jakie były przyczyny tak dużych różnic w pierwszej ćwierci XV stulecia? Czy te zmiany dotyczyły tylko spraw małżeńskich? Na przeszkodzie w ukazaniu szerszych tendencji na pewno stanął wąski zakres chronologiczny przyjęty w omawianej pracy — pierwsze ćwierćwiecze XV stulecia. Ten czas wydaje się stanowczo za krótki, aby można było pokusić się o głębsze analizy zmian zarówno w materii samych spraw małżeńskich, może też zmian społecznych, jak i procedowania konsystorza. Ponadto autorka za podstawę badań ma jedynie protokoły z posiedzeń sądu (acta causarum); osobne serie akt zawierających zeznania świadków (Depositiones testium) istnieją dla diecezji poznańskiej dopiero od 1440 roku, a wyroki (Sententiae) od 1458 roku. Niepełne przekazy źródłowe, odsłaniające jedynie fragmenty toczących się sporów, niejednokrotnie uniemożliwiały stanowcze formułowanie wniosków.

Wreszcie celem pracy było „odtworzenie obrazu problemów nękających [...] małżeństwa" w pierwszej ćwierci XV wieku w diecezji poznańskiej (s. 13). Nie chcę powtarzać po raz kolejny uwagi, że w sporej grupie spraw małżeńskich nie mamy do czynienia $\mathrm{z}$ małżeństwami. $\mathrm{W}$ części jednak spraw przyczyną sporów, które trafiły do konsystorza, były faktyczne problemy małżeńskie, jak chociażby przemoc, zdrada (cudzołóstwo), niepłodność. W innych sprawach możemy się domyślać odmiennych komplikacji: niedopasowania partnerów i daleko idących trudności we wspólnym życiu. Tak mogło być w przypadkach, gdy nagle przypominano sobie różne przeszkody małżeńskie, jak choćby pokrewieństwo lub wcześniejsze związki, które niekoniecznie musiały być małżeństwami, ale mogły służyć za pretekst — przynajmniej w mniemaniu jednej ze stron - do wyplątania się z nieudanego obecnego związku. Sama autorka jednak raczej każe czytelnikowi domyślać się problemów małżeńskich zamiast podjąć osobną analizę tego zagadnienia.

$\mathrm{Na}$ osobną uwagę zasługuje wreszcie styl i język monografii. Jest to zwykle punkt drażliwy. Autorzy mają różne nawyki językowe, różne style, które nie zawsze muszą się podobać recenzentom. Tak długo jednak, jak maniera 
językowa mieści się w granicach poprawności gramatycznej i stylistycznej, wytykanie jej autorowi jest nieuzasadnione. Można zwracać uwagę, że tytuły rozdziałów w omawianej pracy są sformułowane w tonie swobodnym, może nawet publicystycznym, i nie pasują do rejestru języka rozprawy naukowej. To uznałabym jednak jedynie za manierę (w jednym przypadku już wcześniej wskazałam na błąd logiczny). Zresztą tak tytuł, jak i spis treści mają zachęcić czytelnika do lektury. Ważna jest zatem atrakcyjna, przykuwająca uwagę forma. Trudno również uznać za błąd próby ożywienia narracji prac naukowych przez zastosowanie swobodniejszego języka. Biniaś-Szkopek próbuje odejść od często nudnego języka naukowych rozpraw. Próby te jednak nie zawsze wypadają dobrze.

Przykłady. Znajdujemy tu wiele wyrażeń kolokwialnych, które rażą w pracy naukowej: ,[...] jej [pracy oficjała - M.S.] wykonywanie nie było szczytem marzeń dla bogatych rodzin możnowładczych” (s. 67); „W chrześcijańskiej Europie wyrastającej na gruzach Imperium Rzymskiego [...]” (s. 99); „Tu następował jednak pewien zgrzyt, gdyż dla Kościoła podstawowym warunkiem [...]” (s. 119); „W wielu jednak sytuacjach oficjał sam pozostawał w kropce" (s. 149).

Fragmenty, które są opisami poszczególnych spraw, wykazują ogromną zależność od języka oryginału. Wierność tłumaczenia jest oczywiście zawsze zaletą, ale zachowanie zasad języka, na który dokonuje się przekładu, nie może być lekceważone. Za przykład niech posłuży jeden passus: „[..] przed poznańskim konsystorzem [toczyła] się sprawa pomiędzy Jadwigą Drozdówną a Piotrem Ratajewiczem z Gołębina. Ona złożyła, że w czasie ostatnich żniw w domu jego matki w Gołębinie on dał jej wiarę małżeńską i odpowiednimi słowami, a następnie współżyciem cielesnym pozbawił ją dziewictwa i uczynił ciężarną. W zamian za zhańbienie wniosła, by jej zadość uczynił, płacąc sześć grzywien. Piotr zaprzeczył, że obiecał małżeństwo, jednak potwierdził jej dziewictwo. W tej sytuacji sędzia zwolnił mężczyznę z zarzutów Jadwigi odnośnie do przysięgi, zezwolił im na inne związki, a w kwestii zadośćuczynienia za sturpo polecił im samy ustalić kompromis w ciągu piętnastu dni, co też uczynili" (s. 151).

Autorka miesza rejestry języka, używa wyrażeń niepasujących do kontekstu, popełnia błędy gramatyczne, stylistyczne i interpunkcyjne: „Warto zaznaczyć, iż pomimo przerwy letniej w sprawach niecierpiących zwłoki, zgodnie z wymogami Dekretałów Grzegorza IX sąd mógł zebrać się, by pochylić się nad problemem” (s. 80). Na stronie 108 czytamy o „ceremonii poświęcenia łóżka małżeńskiego”, a na stronie 224 znajdujemy „stałego małżonka”. Kolejny przykład niefortunnego zdania to: „Śladem przywiązywania do niego [dziewictwa - M.S.] wagi — szczególnie we wcześniejszym średniowieczu była opłata, którą zwano podarunkiem porannym płaconym przez pana młodego na rzecz panny po odbyciu nocy poślubnej. Wniesienie jej było potwierdze- 
niem, że mąż odnalazł swą żonę w stanie dziewiczym" (s. 134). Tu wiele trzeba by było poprawić. Należałoby też zapytać, od czego ma być wcześniejsze owo średniowiecze, ale jest to już tak powszechny błąd, że powoli przestajemy go zauważać. Kilka stron dalej: „Wyznaczony prokurator w imieniu kobiety wniósł petycję, w której stwierdzał, że mężczyzna najpierw obiecał jej małżeństwo, po przyjętej obietnicy rozpoznał ją cieleśnie i spłodził potomka" (s. 149). Na tej samej stronie czytamy, że oficjał — rzecz dotyczy innej sprawy - wydał zarządzenie, aby oskarżony mężczyzna albo pojął za żonę powódkę, z którą wprzód spał, po tym jak obiecał jej małżeństwo, albo wypłacił jej sześć grzywien, albo oczyścił się z zarzutów „samosześć”. Znaczenie tego ostatniego sformułowania autorka słusznie wyjaśnia (jako ,jeden plus pięciu”), ale jego poprawna forma to „samoszóst”. Jest to forma już od dawna nieobecna w języku, więc tym bardziej należało zadbać, aby pojawiła się we właściwym brzmieniu. Przykłady można by mnożyć.

Otrzymaliśmy pracę napisaną językiem trudnym w odbiorze. Stylem zawiłym, chwilami wręcz nieporadnym, nie zawsze też zrozumiałym. Potknięcia i błędy językowe nie są przypadkami odosobnionymi, które można by położyć na karb nieuwagi, a które - co trzeba przyznać ze skruchą - znajdują się w prawie każdej książce. Od prac z dziedziny humanistyki wymaga się jednak nie tylko rzeczowej i poprawnej metodologicznie analizy materiału źródłowego, ale także poprawnej polszczyzny. Nie tylko dzieła literackie, ale też teksty naukowe budują kulturę danego języka.

Zgłoszone krytyczne uwagi nie umniejszają ogromnego waloru monografii Magdaleny Biniaś-Szkopek, jakim jest wprowadzenie do literatury historycznej obszernego i pasjonującego materiału źródłowego. Na uznanie zasługuje trud przeszukiwania akt konsystorza. Już tylko z tych względów jest to praca ważna i zasługująca na dokładne przestudiowanie. Szczególnym jej atutem jest pokazanie praktyki funkcjonowania prawa kanonicznego, choć w ograniczonym czasie i na wybranym terenie. Tym samym wpisuje się ona $\mathrm{w}$ badania nad kulturą prawną, a także nad mentalnością epoki. Zwłaszcza ta ostatnia problematyka jest trudno uchwytna w źródłach, a akta sądowe dostarczają tu wybornego materiału. 